\title{
Transition to online learning due to the outbreak of Coronavirus: students'perceptions and perspectives
}

\author{
Dilfuza BAKHTIYAROVA1, Prof. Dr. Veysel KILIÇ ${ }^{2}$
}

\begin{abstract}
This article aims to present findings of a survey conducted on Turkish students' experiences of online learning in the wake of the outbreak of new coronavirus (COVID-19) around the globe. In the aftermath of the new coronavirus epidemic and the declaration of it as a pandemic by the World Health Organization on March 11 (Iwai, 2020), universities across Turkey were closed in an attempt to slow down its spread. Education was shortly resumed, yet in new settings, as the learning was shifted to virtual classrooms. This was a sudden and unprecedented change for many learners in Turkey. Therefore, this paper intends to examine students' perceptions as well as reactions to such an unforeseen and rapid transition to remote learning. The data obtained from 135 undergraduate students across different universities in Istanbul suggest mixed results. The negative experiences were mainly associated with technical issues, lack of real communication and difficulty with staying focused during online lessons. While convenience and flexibility were reported to as the biggest benefits to this mode of study.
\end{abstract}

Key words: COVID-19, remote learning, virtual classroom, online learning, online platform

1 Istanbul Aydin University, Istanbul, Turkey, dilfuzabakhtiyarova@stu.aydin.edu.tr, ORCID: 0000-0002-1853-5498

2 Istanbul Aydin University, Istanbul, Turkey, vlkilic@aydin.edu.tr https://orcid.org/0000-00026773-9307

Research Article - Submit Date 28.05.2020, Acceptance Date 04.08.2020

DOI: 10.17932/IAU.IJMCL.2015.014/ijmcl_v06i2002 


\section{Coronavirüs'ün Ortaya Çıkması Nedeniyle Çevrimiçi Öğrenmeye Geçiş: Öğrencilerin Algıları Ve Bakış Açıları}

\section{ÖZ}

Bu makale, Türk öğrencilerin dünya çapında yeni koronavirüsün (COVID-19) ortaya çıkması sonucunda internet üzeri (online) öğrenme deneyimleri üzerine yapılan bir araştırmanın bulgularını sunmayı amaçlamaktadır. Yeni koronavirüs salgınının yayılmasından ve bunun 11 Mart'ta Dünya Sağlık Örgütü tarafından pandemi olarak ilan edilmesinden sonra (Iwai, 2020), Türkiye genelindeki üniversiteler yayılmasını yavaşlatmak amacıyla kapatıldı. Eğitim yeni ortama geçilerek, sanal sınıflara taşınarak kısa süre içerisinde devam etti. Bu, Türkiye' deki birçok öğrenci için ani ve benzeri görülmemiş bir değişiklikti. Bu nedenle, bu makale öğrencilerin bu öngörülemeyen hızlı bir geçişe karşı olan tepkilerini ve algılarını incelemeyi amaçlamaktadır. İstanbul'daki farklı üniversitelerdeki 135 lisans öğrencisinden elde edilen veriler karışık sonuçlar vermektedir. Olumsuz yönler temel olarak teknik konular, gerçek iletişim eksikliği ve çevrimiçi derslerde odaklanmada zorluk yaşamak ile ilgiliydi. Buna karşın zaman uyumu ve esnekliğin bu çalışma biçiminin en büyük faydaları olduğu bildirilmiştir.

Anahtar kelimeler: COVID-19, uzaktan ögrenme, sanal sınıf, çevrimiçi ögrenme, çevrimiçi platform

\section{INTRODUCTION}

The outbreak of the novel coronavirus (COVID-19) was first registered in Wuhan, Hubei Province, China in December 2019 (McLeod, 2020). However, it didn't take too long for other countries to get affected as the virus proved to be fast spreading, and in just a few months the infection spread around the globe and became a pandemic.

Typical coronavirus patient develops symptoms very similar to flu which include fever and dry cough. Although these symptoms are quite common, 
they may not manifest themselves at all and the incubation period may last up to 14 days (Mahbubani, 2020). According to the research by Center for Disease Control and Prevention (CDC) an infected person may transmit the virus during this time and may spread it to on average 2.2 others. To limit this spread many states have declared national lockdowns and severely restricted travelling. This has produced a profound effect on people worldwide and it won't be an exaggeration to say that every single being on Earth has been affected to a certain extent. Industries such as tourism, airline, finance and entrepreneurship, etc. have suffered the most resulting in billions of profits lost.

Brief Chronology of the Events in Turkey

Turkey's Health Minister Fahrettin Koca officially announced the first case of coronavirus on March 11, 2020 (Turkish Health Ministry). Following this disclosure, the Minister of National Education in Turkey- Ziya Selcuk announced that all schools would undergo a thorough disinfection. It then (on March 16, 2002) was decided that all schools (primary, secondary and high) would be closed for a week and that all universities would be closed for 3 weeks. Starting on 23 March 2020 it was officially announced that further education in all schools and universities would need to be carried online (from home).

\section{THE PURPOSE}

It's been 8 weeks now since education across all levels in Turkey has been being delivered remotely. While it is not a very long-time span, I think some meaningful conclusions based on students' experiences with remote learning can be drawn. From these conclusions, possible recommendations could also be made. 
Transition to online learning due to the outbreak of Coronavirus: students' perceptions and perspectives

\section{PARTICIPANTS and CONTEXT}

This study comprised 135 students from different universities around Istanbul at an undergraduate level. An electronic survey (via Google Forms) was sent to all students asking about their experiences with online learning. Below are the survey questions that were sent to students.

\section{Survey Questions}

A Google Form survey in English was sent (emailed) to all students to collect their responses.

Below are the questions that the survey asked. All of the questions can be divided into 4 categories namely: Technology, Learning Online and Instructors.

\section{Technology:}

Which online platform is being used for your lessons? (Zoom, Google Meets, BB Collaborate, Other).

How often do you have technical problems? (Never, Sometimes, Often, Always).

Do you prefer your camera on or off during lessons? (On, Off).

Learning Online:

How do you prefer your classes to be? (Fully Online, Face-to-Face, Mixed: online with face-to-face)

Do you think online lessons are as effective as classroom lessons? (No, not at all/ Sometimes/ Most of the time/ Yes, online lessons are as effective as classroom lessons/ Yes, online lessons are more effective than classroom lessons).

Do you find it difficult to focus when learning online? (Always, Sometimes, Often, Never)

Are the online learning materials easy to use? (Yes, very easy, Yes, somewhat easy, No, not easy at all.) 
Do you agree that exams online are easier than exams in the classroom? (Yes, No, I don't know).

What do you think is the biggest advantage of learning online? (Open ended) What do you think is the biggest disadvantage of learning online? (Open ended)

Instructors:

Are you getting the right amount of communication and support from your instructor(s)? (Yes, No).

Do you find it easy to understand your instructor during the lessons online? (Yes very easy, Yes, fairly easy, No, not easy at all).

\section{RESULTS}

This section presents the results of the survey.

Question 1: Which online platform is being used for your lessons? The options to this question included the following commonly used online platforms: Zoom, Google Meet, BB Collaborate and Other. The results reveal that Zoom is by far the most popular online tool currently being used to facilitate remote learning ( $58.5 \%$ or 79 respondents chose this). $30.4 \%$ (41) of the responses were given to "Other". BB Collaborate was cited by $8.1 \%$ (11) respondents, while Google Meet was chosen by only 3\% (4) of students.

Question 2: How often do you have technical problems?

The majority of students $67.4 \%$ (91) said that they sometimes experience technical problems. A further $18.5 \%$ of the respondents $(25)$ reported that they never have these problems. $11.9 \%$ of those surveyed (16) said that they often have such problems, and a mere $2.2 \%$ (3 students) expressed that technical issues are always a problem for them. 
Transition to online learning due to the outbreak of Coronavirus: students' perceptions and perspectives

Question 3: Do you prefer your camera "on" or "off" during lessons?

The vast majority of the votes $71.9 \%$ (97) were given to the "camera off" option, with $28.1 \%$ (38) to "camera on".

Option 4: How do you prefer your classes to be?

This question offered three alternatives: fully online, face-to-face or a mixed (online with face-to-face) mode. The results were mixed. $42.2 \%$ of those surveyed (57) opted for a face-to-face option, with $34.1 \%$ (46) choosing mixed and the rest $(23.7 \%)$ voting for online only mode.

Question 5: Do you think online lessons are as effective as classroom lessons? Just above a third of all respondents (34.8\%) found online lessons not at all as effective as classroom lessons. A slightly higher proportion $37 \%$ (50) ranked them as sometimes effective, with a further $22.2 \%$ (30) saying that online lessons were equally effective to online lessons most of the time. The remaining $5.9 \%$ (8) of the students maintained that lessons online are always effective.

Question 6: Do you find it difficult to focus when learning online? Again, the most commonly picked option was "sometimes" $(54.8 \%$ or 74 students). For $18.5 \%$ (25) of the respondents staying focused is often a problem. Similarly, 17\% (23) said that it is always a problem. 9.6\% (13) of those surveyed said that it is never difficult to focus when studying online.

Question 7: Are the online learning materials easy to use?

For $54.8 \%$ (74) of the students surveyed, online materials are somewhat easy to use. However, $39.3 \%$ (53) find them very easy to use with only $5.9 \%$ (8) stating that using online materials is not easy at all. 
Question 8: Do you agree that exams online are easier than exams in the classroom?

This question produced mixed results with the biggest proportion (39.3\%) of students agreeing with the question (53). 33.3\% (45) students disagreed and $27.4 \%$ (37) said that they don't know yet.

Question 9: Do you find it easy to understand your instructor during the lessons online?

For almost a half of all respondents (48.9\%) it's fairly easy, with additional $33.3 \%$ (45) for whom it is very easy. $17.8 \%$ (24) think that it isn't easy to understand their teacher.

Question 10: Are you getting the right amount of communication and support from your instructor(s)?

$55.6 \%$ of all responses (75) were positive with only $7.4 \%$ (10) negative and the remaining $37 \%$ (50) neutral.

Question 11: What do you think is the biggest advantage of learning online? Given the open-ended nature of this question, the responses varied. However, the most commonly cited advantages related to convenience and flexibility that online learning can provide. Another very popular benefit was its time saving potential. Quite a few of the respondents saw absolutely no advantages of online learning.

Some of the responses included: "easier to concentrate", "no other student disturbs me".

A few other recurring responses were "easier" than face-to-face learning as students experienced "less anxiety", it was "easier to participate" and "easier to communicate"

Other responses were non-recurring and included: "it's a new skill”, "I can sleep longer", "safe environment", "it saves our energy because of not 
Transition to online learning due to the outbreak of Coronavirus: students' perceptions and perspectives

going to school”.

Question 12: What do you think is the biggest disadvantage of learning online?

This was another open-ended question which yielded various results. The range of answers was extensive as students picked up on many different shortcomings of online learning. Some of the most frequently mentioned ones were related to connectivity issues and other technical problems. Lack of real communication and external distractions and limited interaction were among other common downsides referred to by students.

Instructors' inability to control class appropriately and unpreparedness to use technology resulting in students' time wasted were also mentioned as some of the drawbacks related to online learning.

Other cited disadvantages included: "being at home is boring", "inability to teamwork", "teacher-centeredness", "a lot of homework".

\section{Discussion of Results}

Based on the data gathered it could be concluded that the students who took part in this survey had different experiences with online learning. This is predictable as the participants were all from various universities around Istanbul and were exposed to different teaching methods.

Overall, it can be said that students didn't express strong preference to either online or face-to-face learning. It is obvious that online education, although associated with certain difficulties, has a great potential and if managed appropriately might be as effective as a brick-and-mortar classroom. What's more, it could be inferred from the data that there's a lean away from the physical classroom, as the majority $(57.8 \%)$ would prefer their studies to be either mixed (online with face-to-face) or fully online.

Flexibility and time-saving factors were cited as the major benefits to studying online. These are crucial given the increased pace of life. With 
online classes, students have an opportunity to fit their learning into their busy schedule and save a great amount of time- the perks which a traditional face-to-face education doesn't offer (Brooks, 2019). Besides, many students maintained that it was easier for them to express themselves, as they didn't feel any pressure neither from their teacher nor from peers.

It's also worth noticing that although lack of real communication was cited as a drawback of studying online, the majority said that they found it easy to understand their instructors. Similarly, just over a half thought that they were receiving enough support from their teachers. What's more, virtually all students said that learning materials were fairly easy to use. This is particularly reassuring giving the fact that for many educators across Istanbul this has also been a new experience. This implies that teachers managed to swiftly transit into a new realm and continue to do their best to provide the most favourable outcome and support to their learners.

Despite the clear advantages, connectivity issues and other technical problems seem to be the major stumbling blocks of online education. It is frustrating to get disconnected or be unable to join a classroom because of poor or unstable connection. This creates additional problems and makes online learning experience unsettling to many students.

In addition, "lack of real interaction" was among recurring dissatisfactions with online learning. This is totally understandable as students suddenly were "forced" to switch into remote learning, which gave them only little time to adjust to the new "classroom". Furthermore, students' frustration aggravated due to the fact that they had to stay at home as a quarantine measure, which contributed to the feeling of loneliness and possible boredom. Had the students had the opportunity to socialize and meet their friends during that time, the "lack of interaction" might have been less frequently reported.

Some other commonly reported problems with learning online were difficulty to concentrate and stay focused. Students often have to stay in front of the screen for several consecutive hours trying to concentrate. This is both mentally 
Transition to online learning due to the outbreak of Coronavirus: students' perceptions and perspectives

and physically tiring resulting in students' level of concentration receding and motivation dwindling. Although it is hard to deny that concentration is a big issue in online learning and that many learners genuinely struggle with it, some students knowingly undermine their potential to stay focused by studying "from bed". "Studying without having to leave the bed" or "eating while studying" were given as some of the positives of online learning. If that is the case, the concentration issues are not surprising.

\section{CONCLUSION}

The outbreak of coronavirus that we are yet to overcome has changed education around the globe dramatically. Online learning isn't always perfect for everyone as it requires a certain degree of self-motivation and autonomy. Inability to manage time and take control of learning won't turn out a positive online experience for anyone. However, one trend is obvious, online education is evolving rapidly and has already reached the turning point when it can challenge the physical classroom by offering greater flexibility and requiring less time investment. This means that further research into e-learning should be our priority. Investing time and money into educational technologies to increase online learning efficiency is definitely worthwhile and the pandemic that we are all living through has proven that.

Present survey has demonstrated that despite developments in technology the very technology remains to be the biggest obstacle. This suggests that improving the Internet technologies have to be our primary priority if our aim is to continue with education online (which is a very likely scenario). On top of that, course designs need to be revisited with the learning material being digitized to better suit online delivery. One more suggestion may be for the teachers to make their students turn their cameras "on" during the sessions, which may alleviate problems related to concentration and lack of participation. Finally, it may be worthwhile to conduct more surveys on students' online experiences when the situation with the COVID-19 stabilizes 
and life gets back to normal. The results may be surprisingly different.

\section{BIBLIOGRAPHY}

Brooks, A. (January, 2019). Breaking Down the Pros and Cons of Online Classes. https://www.rasmussen.edu/student-experience/college-life/prosand-cons-online-classes/. Rasmussen College.

Centers for Disease Control and Prevention: https://www.cdc.gov/ retrieved 01.05.2020

Coronavirus Statistics: https://www.worldometers.info/coronavirus/ retrieved 01.05.2020

Daily Sabah (April, 2020). School closures in Turkey extended until May 31 amid COVID-19 pandemic. https://www.dailysabah.com/turkey/schoolclosures-in-turkey-extended-until-may-31-amid-covid-19-pandemic/news. Daily Sabah

Iwai, Y. (March, 2020). Online Learning During the COVID-19 Pandemic. https://blogs.scientificamerican.com/observations/online-learning-duringthe-covid-19-pandemic/. Scientific American.

Li, C. and Lalani, F. (April, 2020). The COVID-19 pandemic has changed education forever. This is how. https://www.weforum.org/agenda/2020/04/ coronavirus-education-global-covid19-online-digital-learning/. World Economic Forum.

Mahbubani, R., Perper, R., McFall-Johnsen, M. (April, 2020). 26 questions about the coronavirus, answered - from who's most at risk to where new cases are spreading. Business Insider.

McLeod, V. (March, 2020). Covid-19: A History of Coronavirus. https://www. labmanager.com/lab-health-and-safety/covid-19-a-history-of-coronavirus-22021. Lab Manager.

World Health Organization (29 April, 2020). Coronavirus disease (COVID-19) advice for the public https://www.who.int/emergencies/diseases/novelcoronavirus-2019/advice-for-public 